\title{
BMJ Open Who actually receives cell phone use while driving citations and how much are these laws enforced among states? A descriptive, cross-sectional study
}

\author{
Toni M Rudisill, ${ }^{1}$ Motao Zhu ${ }^{1,2}$
}

To cite: Rudisill TM, Zhu M. Who actually receives cell phone use while driving citations and how much are these laws enforced among states? A descriptive, crosssectional study. BMJ Open 2016;6:e011381.

doi:10.1136/bmjopen-2016011381

- Prepublication history for this paper is available online. To view these files please visit the journal online (http://dx.doi.org/10.1136/ bmjopen-2016-011381).

Received 3 February 2016 Revised 17 May 2016 Accepted 19 May 2016

CrossMark

\footnotetext{
${ }^{1}$ Injury Control Research Center, West Virginia University, Morgantown, West Virginia, USA

${ }^{2}$ Department of

Epidemiology, West Virginia University, Morgantown, West Virginia, USA
}

Correspondence to Dr Motao Zhu; mozhu@hsc.wvu.edu

\section{ABSTRACT}

Objectives: While numerous cell phone use while driving laws have been passed among states, little information exists regarding who gets cited for these traffic infractions and how much these laws are enforced at the state-level within the USA.

Design: Cross-sectional, descriptive study.

Setting: 14 states and the District of Columbia. Participants: Those receiving cell phone use while driving citations within included states from 2007 to 2013

Primary outcome: Demographic characteristics of cited drivers were assessed. Rates of infractions per 100000 licensed in-state drivers per year for various cell phone use while driving violations were calculated.

Results: Drivers were cited for hand-held use violations $(\mathrm{n}=2.5$ million) more than texting $(\mathrm{n}=14 \mathrm{682})$ or young driver all cell phone bans $(n=342)$. Among states that provided data for all traffic violations, cell phone use while driving citations comprised $1 \%$ of all written citations. Regardless of ban type, males (68.2\%) were cited more frequently than females. Drivers 25-64 years of age $(90.8 \%)$ were more likely to be cited for hand-held phone use. The average yearly rate of infractions per 100000 licensed in-state drivers from 2010-2013 was 5.8 for texting bans, 2607 for hand-held bans, and 9954 for any traffic violation.

Conclusions: Among cited drivers, age and sex differences existed by the type of ban violated. State-level enforcement appeared sparse. Due to the potential serious consequences of cell phone use while driving in the USA, more enforcement and targeted public safety campaigns are likely needed.

\section{INTRODUCTION}

According to the Federal Communications Commission, there were over 302 million cell phone subscribers in the USA in $2013 ;^{1}$ this implies that $\sim 95 \%$ of the US population had a cell phone subscription. Therefore, mobile technologies have become an integral component of US culture. While this technology has its benefits, it introduces numerous psychological and social issues ${ }^{2}$ and may contribute to driver distraction. According to the

\section{Strengths and limitations of this study}

- Citation data for cell phone use while driving offenses were collected from 14 states and the District of Columbia.

- This is the first study to assess violator characteristics and enforcement across multiple states in the USA for cell phone use while driving citations.

- This study was based on written citations and not convictions, which may differ.

- This study investigated state-level enforcement only, and not local enforcement efforts.

results of a 2014 US national survey, $~ 36 \%$ of drivers self-reported that they read a text message/email, $27 \%$ typed/sent a text message/email, $69 \%$ talked on a cell phone, and $17 \%$ accessed the internet while they drove in the 30 days prior to survey. ${ }^{3}$ As for roadside observed cell phone use while driving behaviours, the findings of the 2014 National Occupant Protection Use Survey (NOPUS) showed that $4.3 \%$ of drivers were observed holding a hand-held cell phone and $2.2 \%$ were seen visibly manipulating a mobile device while they drove at randomly sampled intersections throughout the US. ${ }^{4}$ The 2014 NOPUS results also showed that roadside observed hand-held phone use differs by sex and age; $\sim 5.1 \%$ of female and $3.6 \%$ of male drivers were observed using a hand-held cell phone, while $5.8 \%$ of drivers aged 16-24, 4.3\% of drivers aged 25-69, and $0.8 \%$ of drivers $\geq 70$ years of age were observed holding a cell phone to their ear while driving. ${ }^{4}$ Additionally, $4.8 \%$ of drivers aged $16-24$ and $2.0 \%$ of drivers aged 25-69 were seen visibly manipulating hand-held devices while driving. ${ }^{4}$

The use of cellular phones while driving is not without consequence. It is well established in the literature that manipulating 
mobile technologies while operating a motor vehicle can negatively affect a driver's performance. Numerous cell phone use while driving studies have been conducted to date, including epidemiologic, laboratory simulation and naturalistic driving experiments. Numerous studies have shown typing and reading text messages while driving can affect eye movements, reactions times, collisions, lane positioning, speed and distance. ${ }^{5}$ Various naturalistic studies have shown that dialling, locating a phone, and texting increase the risk of a driver encountering a safety-critical event (ie, collision or near-collision).$^{6}$ Epidemiological studies show that increased cell phone use is associated with an increase in motor vehicle collision. ${ }^{7}{ }^{8}$ Meta-analytic studies have shown that cell phone conversations also affect driver performance. ${ }^{9}$

Therefore, in an effort to protect the public, numerous cell phone use while driving laws have been passed among states. These laws can typically be categorised as either hand-held cell phone bans, texting while driving bans or young driver all cell phone bans. In the USA, texting bans typically bar drivers from manually composing or answering text messages, but drivers can still talk on hand-held cell phones and drive. Hand-held cell phone bans typically restrict drivers from holding a cell phone and talking while driving. Young driver all cell phone bans typically prohibit young or novice drivers from any cell phone use while driving behaviours (except in emergency situations) such as talking, texting, dialling, emailing and/or accessing the internet while driving. As of January 2016, 14 states and the District of Columbia (DC) prohibit drivers from using hand-held cell phones while driving, while 46 states and DC ban text messaging for all drivers. ${ }^{10}$ Additionally, 38 states and DC ban all cell phone use while driving for young or novice drivers. ${ }^{10}$

While states can have a combination of driving laws in effect, it does not necessarily guarantee their enforcement. Police work is highly discretionary and a substantial body of literature exists regarding as to why police officers choose to write citations to individuals they stop for traffic infractions. ${ }^{11-20}$ Despite the research on officer behaviour and the passage of numerous cell phone use while driving laws, very little research exists in the USA regarding cell phone use while driving citations and the level of enforcement among states. To the authors' knowledge, only four studies have enumerated the frequency of cell phone use while driving citations written, but most were limited to one or two states. Mccartt and Geary $^{21}$ found that during the first 15 months of enactment, cell phone use while driving citations represented only $2 \%$ of all traffic citations written by New York state police. McCartt and Hellinga ${ }^{22}$ found that from August 2004 to October 2005, only 8\% of the DC's moving violations consisted of hand-held phone convictions. From 2006 to 2011, it was estimated that cell phone violations made up $\sim 3 \%$ of all moving traffic violations issued in New Jersey. ${ }^{23}$ Citation rates in
Washington state and North Carolina were also found to be very low compared to other traffic violations such as seat belt usage. ${ }^{24}$ No studies have enumerated the frequency of cell phone use while driving citations written across multiple states. Owing to the apparent gap in the literature, the purpose of this analysis was to describe who actually receives citations for cell phone use while driving offenses and to discern how many citations were issued across multiple states. The hypotheses for this analysis were: (1) age and sex differences would exist by the type of ban violated, and (2) the number of citations written for cell phone use while driving would comprise less than $10 \%$ of all written traffic citations across states.

\section{METHODS}

\section{Data sources}

All 50 states, including DC, were contacted and asked to provide data for all moving traffic citations written by state police from 1 January 2007 to 31 December 2013. The variables requested were: the date and time of the incident, violation code and description, county where the violation occurred and driver demographics. The collection of citation data between states was not uniform and highly variable. States differed in where they stored the data (ie, Administrative Office of the Courts, Department of Motor Vehicles, Department of Public Safety, or State Police). Some states only retained records for a limited duration. The types of information recorded about the driver or traffic encounter were also highly varied. Some states did not have a centralised database in which they stored records and could not provide data. Some states could only provide data pertaining to cell phone use while driving cases and not all traffic violations. In addition to DC, 14 states provided useable data for this analysis which included Alaska, Connecticut, Kentucky, Massachusetts, Michigan, Mississippi, North Carolina, North Dakota, Nebraska, New York, Ohio, Utah, Washington, and Wyoming. Data from these states could be pooled because they were systematically collected, could be coded, and were fairly complete. A summary of the citation data collected from these states and used in the analyses are presented in table 1 along with each states' cell phone use while driving laws and when they were enacted (through 12/ $31 / 2013)$; the information pertaining to the laws in effect and their enactment date were obtained from the Governor's Highway Safety Association. ${ }^{10}$ In addition to the citation data, the number of licensed drivers by state per year were obtained through the Federal Highway Administration ${ }^{25}$ in order to calculate rates of infractions for each cell phone use while driving violation per year per 100000 licensed in-state drivers.

\section{Variables}

The independent variables of interest included: age, sex, whether the person receiving the citation was licensed in the state where the offense was committed, the day of 
Table 1 Summary of citation data collected by states for analysis*

\begin{tabular}{|c|c|c|c|c|}
\hline State & $\begin{array}{l}\text { Complete data } \\
\text { years included } \\
\text { in analysis }\end{array}$ & $\begin{array}{l}\text { Provided data for cell } \\
\text { phone use while driving } \\
\text { violations only }\end{array}$ & $\begin{array}{l}\text { Provided data } \\
\text { for all traffic } \\
\text { violations }\end{array}$ & $\begin{array}{l}\text { Type of cell phone use while } \\
\text { driving law and the year of } \\
\text { enactment (thru 12/31/2013) }\end{array}$ \\
\hline Alaska & 2009-2013 & & $x$ & TB 2008 \\
\hline Connecticut & 2007-2013 & & $x$ & HB 2005; TB 2005; YDB 2005 \\
\hline $\begin{array}{l}\text { District of } \\
\text { Columbia }\end{array}$ & 2008-2013 & & $\mathrm{X}$ & HB 2004; TB 2004; YDB 2004 \\
\hline Kentucky & 2011-2013 & $x$ & & TB 2010; YDB 2011 \\
\hline Massachusetts & 2011-2013 & $x$ & & TB 2010; YDB 2010 \\
\hline Michigan & 2011-2013 & $x$ & & TB 2010; YDB 2013 \\
\hline Mississippi & 2012-2013 & & $\mathrm{X}$ & TB-S 2011 \\
\hline North Carolina & 2010-2013 & & $\mathrm{X}$ & TB 2009; YDB 2006 \\
\hline North Dakota & 2012-2013 & $x$ & & TB 2011; YDB 2012 \\
\hline Nebraska & 2011-2013 & & $\mathrm{X}$ & TB 2010; YDB 2008 \\
\hline New York & 2010-2013 & $x$ & & HB 2001; TB 2009 \\
\hline Ohio & 2013 & & $\mathrm{X}$ & TB 2012; YDB 2012 \\
\hline Utah & 2012-2013 & & $\mathrm{X}$ & HB 2007; TB 2009; YDB 2013 \\
\hline Washington & 2008-2013 & & $\mathrm{X}$ & HB 2007; TB 2007; YDB 2010 \\
\hline Wyoming & 2011-2013 & & $\mathrm{X}$ & TB 2010 \\
\hline
\end{tabular}

week and season when the citation was issued. The categorisation of these variables is presented in table 2 . Ages were grouped as 15-17, 18-24, 25-64, and $\geq 65$. Because risk taking behaviours differ by age and crash risk over the lifespan is curvilinear (ie, U-shaped), ${ }^{26}$ this categorisation separated teen drivers, college-aged drivers, the 'average driver', and older drivers, respectively. In regards to season, winter included December thru February, spring included March thru May, summer included June thru August, and fall included September thru November. The dependent variable was the type of violation in which the driver committed. This included texting while driving offenses, hand-held cell phone use while driving offenses, a young driver all cell phone ban violation, and all traffic citations (including cell phone use while driving citations) combined.

\section{Statistical analysis}

Because many states passed cell phone use while driving legislation during the study period, the analyses were limited to data years after the law was passed for each state. For example, if a state passed a texting while driving law in 2010, only data from 2011 to 2013 would be used in the analysis for texting violations. This was done to fully capture enforcement efforts.

To assess the demographic characteristics of individuals receiving citations for specific law violations, frequencies and percentages were calculated for texting while driving violations, hand-held cell phone use while driving, and young driver all cell phone ban violations. A state could contribute data only if they had passed the law of interest. Therefore, all 14 states (Alaska, Connecticut, Kentucky, Massachusetts, Michigan, Mississippi, North Carolina, North Dakota, Nebraska, New York, Ohio,
Utah, Washington, and Wyoming) and DC could have cited individuals for texting while driving violations. Only four states (Connecticut, New York, Utah, and Washington) and DC could have cited drivers for handheld cell phone use while driving. Several states passed young driver all cell phone bans during the study period. The data for Utah and Michigan could not be used in the calculations for young driver all cell phone bans as they passed this legislation during 2013. Therefore, only eight states (Connecticut, Kentucky, Massachusetts, North Carolina, North Dakota, Nebraska, Ohio and Washington) and DC could be included in these specific calculations. Pearson's $\chi^{2}$ Tests for Independence (for nominal data) and Cochran Armitage Trend tests (for ordinal data) were conducted to formally compare the demographic characteristics of violators for each law. Frequencies and percentages were also calculated for all traffic citations issued (including cell phone use while driving) to summarise the data from all states in the analysis. Since not all states provided data for all traffic citations issued, the proportion of cell phone use while driving citations compared to all other traffic citations was calculated using nine states (Alaska, Connecticut, Mississippi, North Carolina, Nebraska, Ohio, Utah, Washington and Wyoming) and DC who supplied data pertaining to all traffic violations.

Rates of citation for texting while driving, hand-held cell phone use, and any traffic citation were calculated by dividing the number of infractions committed by in-state drivers for each type of offense by year by the number of licensed drivers per state per year. Young driver all cell phone ban rates were not calculated because so few citations were written for this violation. Rates of citation for all traffic violations were limited to 
Table 2 Demographic characteristics of apprehended drivers by type of traffic violation in select states, USA $\dagger$

\begin{tabular}{|c|c|c|c|c|c|c|c|}
\hline & \multicolumn{2}{|c|}{$\begin{array}{l}\text { Texting violations } \\
(\mathrm{N}=14682) \ddagger\end{array}$} & \multicolumn{2}{|c|}{$\begin{array}{l}\text { Hand-held violations } \\
(\mathrm{N}=2522350) \S\end{array}$} & \multicolumn{2}{|c|}{$\begin{array}{l}\text { Young driver ban } \\
\text { violations }(\mathrm{N}=342) \rrbracket\end{array}$} & \multirow{2}{*}{$\begin{array}{l}\text { All traffic citations } \\
(\mathrm{N}=12758958)^{\star \star} \\
\mathrm{N}(\%)\end{array}$} \\
\hline & $\mathbf{N}(\%)$ & p Value & $\mathbf{N}(\%)$ & p Value & $\mathbf{N}(\%)$ & p Value & \\
\hline \multicolumn{8}{|l|}{ Demographics } \\
\hline Age (in years) & & * & & * & & * & \\
\hline $15-17$ & $103(1.1)$ & & $528(0.0)$ & & 150 (81.1) & & $54698(0.5)$ \\
\hline $18-24$ & 2862 (30.6) & & $155793(6.4)$ & & $35(18.9)$ & & $1810848(18.0)$ \\
\hline $25-64$ & $6323(67.7)$ & & $2229662(90.8)$ & & NA & & 7931035 (78.9) \\
\hline$\geq 65$ & $52(0.6)$ & & 68874 (2.8) & & NA & & $260340(2.6)$ \\
\hline Missing & 5342 & & 67493 & & 157 & & 2702037 \\
\hline Sex & & * & & * & & * & \\
\hline Male & $6742(56.4)$ & & 1937440 (76.9) & & 194 (56.7) & & 7585692 (68.2) \\
\hline Female & $5220(43.6)$ & & $582856(23.1)$ & & 148 (43.3) & & 3541444 (31.8) \\
\hline Missing & 2720 & & 2054 & & 0 & & 1631822 \\
\hline In-state violators & & * & & * & & * & \\
\hline Yes & 7429 (55.2) & & 2056716 (82.2) & & 175 (51.2) & & 9898499 (85.8) \\
\hline No & 6019 (44.8) & & 445605 (17.8) & & 167 (48.8) & & 1641948 (14.2) \\
\hline Missing & 1234 & & 20029 & & 5 & & 1218511 \\
\hline Day of week & & * & & * & & 0.70 & \\
\hline Mon-Thurs & 7288 (63.9) & & 1758405 (69.7) & & 201 (58.8) & & 7625463 (59.8) \\
\hline Fri-Sun & 4122 (36.1) & & 763945 (30.3) & & 141 (41.2) & & $5130141(40.2)$ \\
\hline Missing & 3272 & & 0 & & 0 & & 3354 \\
\hline Season & & * & & * & & 0.09 & \\
\hline Winter & $2100(18.4)$ & & 587615 (23.3) & & $73(21.4)$ & & 3053739 (23.9) \\
\hline Spring & $2554(22.4)$ & & 758206 (30.1) & & 85 (24.9) & & 3455816 (27.1) \\
\hline Summer & 3454 (30.3) & & 621579 (24.6) & & 99 (29.0) & & 3293759 (25.8) \\
\hline Fall & 3302 (28.9) & & $554950(22.0)$ & & 85 (24.9) & & 2952290 (23.2) \\
\hline Missing & 3272 & & 0 & & 0 & & 3354 \\
\hline \multicolumn{8}{|c|}{ 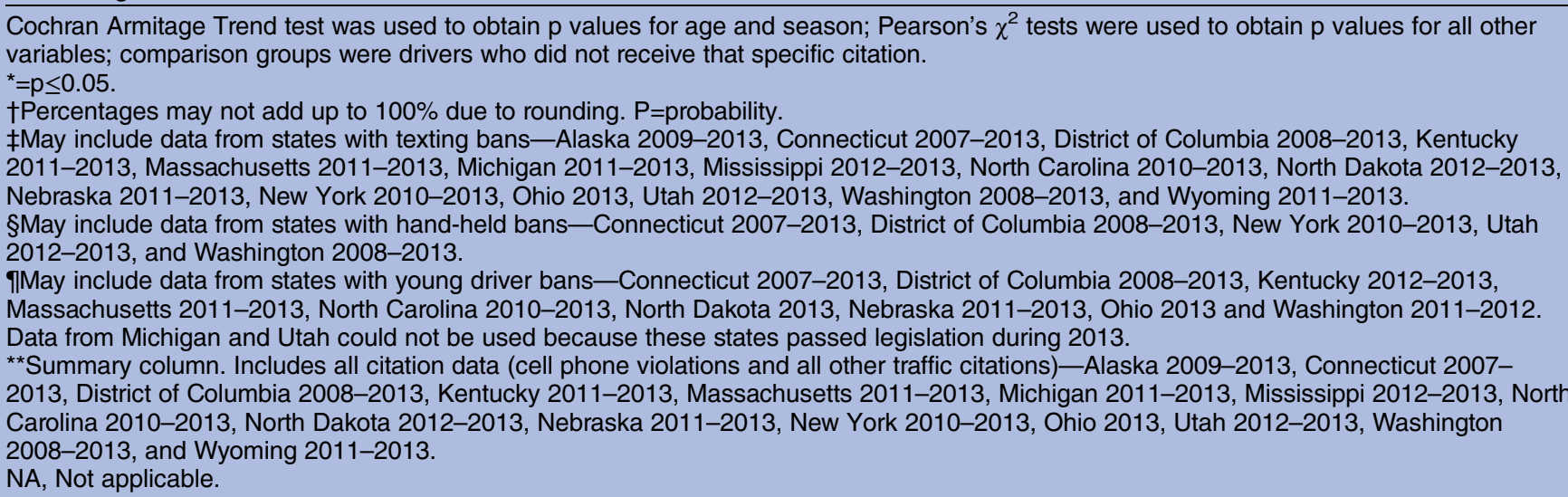 } \\
\hline
\end{tabular}

the states that provided data for all traffic citations written. While rates of citation were calculated for each year from 2007 to 2013, only yearly rates from 2010 to 2013 were presented because the majority of states contributed to these years. The rates of citation were calculated overall, by sex, and by age group. The average yearly rate of citation was calculated by adding the yearly rates together (2010-2013) and dividing by 4 . All rates, counts and frequencies were obtained using SAS/STAT software V.9.3.

\section{RESULTS}

The demographic characteristics of apprehended drivers by the type of traffic violation are presented in table 2. Of the three main cell phone use while driving laws investigated, hand-held cell phone use while driving citations were issued the most $(n=2522350)$, whereas young driver all cell phone ban violations were issued the least $(n=342)$. Regardless of the type of infraction, generally 18-64-year-old drivers (96.9\%) were cited more frequently than younger $(<1 \%)$ or older age groups $(2.6 \%)$. There were significant differences noted in the proportions of citations written by age and sex for each type of ban. In general, males received more citations than females regardless of the offense; the divide between the sexes was less pronounced in terms of texting while driving violations. Regardless of the law violated, most of the drivers cited 
committed their infraction within their state of residence during the weekday.

Among states that provided data for all written citations, cell phone use while driving violations comprised $1 \%$ of all written citations (figure 1 ). The rates of infractions per 100000 licensed in-state drivers per year by violation type are presented in table 3 . In general, the average rate of texting while driving infractions from 2010 to 2013 was considerably lower (5.79) than the average hand-held use while driving infraction (2606.9). Regardless of the law violated, males typically had higher rates of infractions than females. The average rate of infractions from 2010 to 2013 were highest in the 1824-year-old age group for texting violations (12.50), while the rate of infraction was highest in the 2564-year-old age group for hand-held cell phone use while driving violations (3262.9).

\section{DISCUSSION}

The main findings of this analysis were, (1) age and sex differences existed depending on which cell phone use while driving law was violated, (2) cell phone use while driving citations comprised $1 \%$ of all written citations among states that provided data for all traffic citations written, and (3) hand-held use while driving citations were issued more than texting while driving or young driver all cell phone ban violations. These findings potentially suggest that sex and generational differences may influence driver behaviour. These findings may also indicate that hand-held cell phone bans have less barriers to enforcement than texting or young driver all cell phone bans as more hand-held use citations were written.

The findings of this analysis are consistent and explainable by the current literature. Previous traffic

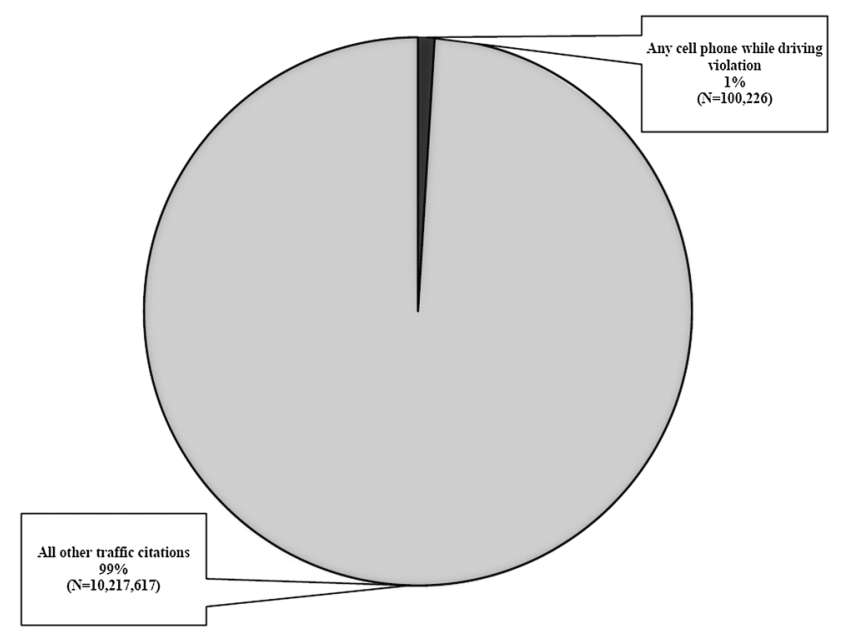

Figure 1 Proportion of cell phone use while driving violations among states that provided data for all traffic violations. Includes data from Alaska, Connecticut, District of Columbia, Mississippi, North Carolina, Nebraska, Ohio, Utah, Washington, and Wyoming. safety research has shown that men are more likely to receive traffic citations ${ }^{27}$ and engage in more risky driving behaviours compared to women, ${ }^{28} 29$ even though the 2014 NOPUS study found women talked on their cell phones while driving slightly more than males. ${ }^{4}$ Previous research has also suggested that women receive more verbal warnings as opposed to written citations by law enforcement compared to men. ${ }^{15}$ It is also known that males drive more frequently than females throughout the life span; ${ }^{30}$ because of this, males may spend more time 'at-risk' of receiving a citation compared to women. Therefore, it is expected that men would receive more citations than women for cell phone use while driving violations.

The findings related to age are also consistent with the current literature. In this analysis, younger drivers (ie, 18-24 years) were cited more for texting while driving, whereas drivers 25-64 years of age were cited slightly more for hand-held cell phone use while driving. Previous research has shown that age differences do exist regarding cell phone use behaviours and attitudes. ${ }^{31-33}$ Based on previous research, drivers aged 25-64 years who use cell phones while driving tend to talk on their phones more than text message; drivers 18-24 years typically have a higher prevalence of texting while driving compared to other age groups. ${ }^{32}{ }^{33}$ In this analysis, the youngest drivers (ie, 15-17 years of age) and oldest drivers (ie, $\geq 65$ years) were cited for cell phone use while driving less frequently, which may also be explainable. Drivers 15-17 years of age are often regulated by graduated driver licensing laws; these laws typically place additional restrictions on these drivers and require more supervised driving by an adult driver. $^{34} 35$ Therefore, these additional restrictions may have influenced the citation rate among the youngest drivers. The oldest drivers (ie, $\geq 65$ years) often try to mitigate collision risk and typically do not engage in high risk behaviours while driving. ${ }^{36}$

In regards to enforcement, cell phone use while driving is known to pose a unique challenge to law enforcement officers. ${ }^{37}$ There may be several explanations as to why drivers were cited more often for handheld use while driving violations compared to texting while driving or young driver all cell phone ban violations. Most of these explanations suggest that hand-held cell phone use while driving may have less barriers to enforcement than the other cell phone use while driving laws. First, if a law has an age specification, such as a young driver all cell phone ban, an officer may not be comfortable apprehending a driver if they cannot clearly assess their age. This phenomenon has been seen in other US traffic safety research, particularly the requirement of decals (ie, decal laws) on the cars of young drivers in New Jersey. Younger drivers were apprehended $14 \%$ more for graduated driver licensing violations after the decal law went into effect, as the decal designation likely made them more identifiable to police. ${ }^{38}$ A second explanation could be that those 
Table 3 Overall number of infractions committed by in-state residents per 100000 licensed drivers per year for each type of cell phone use while driving violation*

\begin{tabular}{|c|c|c|c|c|c|c|}
\hline Violation & Grouping & 2010 & 2011 & 2012 & 2013 & Average Rate† \\
\hline \multirow[t]{8}{*}{ Textingł } & Overall & 2.39 & 4.83 & 6.75 & 9.19 & 5.79 \\
\hline & & & & & & \\
\hline & Males & 2.72 & 5.03 & 6.63 & 9.61 & 6.00 \\
\hline & $\begin{array}{l}\text { Females } \\
\text { Age (vears) }\end{array}$ & 2.05 & 3.77 & 5.46 & 6.93 & 4.55 \\
\hline & $15-17$ & 7.04 & 11.06 & 5.86 & 8.24 & 8.05 \\
\hline & $18-24$ & 5.84 & 12.64 & 13.80 & 17.70 & 12.50 \\
\hline & $25-64$ & 2.10 & 2.92 & 4.33 & 6.64 & 4.00 \\
\hline & $\geq 65$ & - & 0.15 & 0.23 & 0.29 & 0.17 \\
\hline \multirow[t]{9}{*}{ Hand-held use§ } & Overall & 3769.61 & 2733.29 & 2194.09 & 1730.61 & 2606.90 \\
\hline & Sex & & & & & \\
\hline & Males & 5896.51 & 4210.82 & 3281.68 & 2448.24 & 3959.31 \\
\hline & Females & 1678.12 & 1289.73 & 1145.72 & 1048.93 & 1290.63 \\
\hline & Age (years) & & & & & \\
\hline & $15-17$ & 80.96 & 46.98 & 51.41 & 52.04 & 57.85 \\
\hline & $18-24$ & 2398.61 & 1721.47 & 1426.64 & 1218.11 & 1691.21 \\
\hline & $25-64$ & 4753.99 & 3438.12 & 2727.24 & 2132.49 & 3262.96 \\
\hline & $\geq 65$ & 514.87 & 436.05 & 402.27 & 361.15 & 428.59 \\
\hline \multirow[t]{9}{*}{ Any traffic infraction } & Overall & $12,035.94$ & $10,549.44$ & 9261.16 & 7968.45 & 9953.75 \\
\hline & Sex & & & & & \\
\hline & Males & $15,900.59$ & $13,688.71$ & $12,090.20$ & $10,193.42$ & $12,968.23$ \\
\hline & Females & 8541.95 & 7469.30 & 6663.58 & 5646.49 & 7080.33 \\
\hline & Age (years) & & & & & \\
\hline & $15-17$ & 8126.99 & 6839.74 & 4923.03 & 4439.62 & 6082.35 \\
\hline & $18-24$ & $24,016.91$ & $20,223.77$ & $17,521.51$ & $16,237.02$ & $19,499.08$ \\
\hline & $25-64$ & $12,018.40$ & $10,525.00$ & 9316.98 & 8837.05 & $10,174.36$ \\
\hline & $\geq 65$ & 1406.77 & 1364.19 & 1340.08 & 1324.88 & 1358.98 \\
\hline
\end{tabular}

${ }^{*}$ Rates were calculated by dividing the number of violations from in-state residents by the number of 100000 licensed drivers from each included state each year. Only data from 2010-2013 were presented because most states contributed data to these years.

†The average rate was obtained by adding rates from 2010-2013 and dividing by 4 .

¥May include data from states with texting bans-Alaska 2009-2013, Connecticut 2007-2013, District of Columbia 2008-2013, Kentucky 2011-2013, Massachusetts 2011-2013, Michigan 2011-2013, Mississippi 2012-2013, North Carolina 2010-2013, North Dakota 2012-2013, Nebraska 2011-2013, New York 2010-2013, Ohio 2013, Utah 2012-2013, Washington 2008-2013, and Wyoming $2011-2013$.

§May include data from states with hand-held bans-Connecticut 2007-2013, District of Columbia 2008-2013, New York 2010-2013, Utah 2012-2013, and Washington 2008-2013.

ๆMay Include data from states that supplied data on all traffic citations-Alaska 2009-2013, Connecticut 2007-2013, District of Columbia 2008-2013, Mississippi 2012-2013, North Carolina 2010-2013, Nebraska 2011-2013, Ohio 2013, Utah 2012-2013, Washington 2008-2013, and Wyoming 2011-2013.

talking on a cell phone maybe easier to identify at a distance as opposed to those simply texting. Therefore, if an officer sees an individual handling or manipulating a phone while driving, it may be easier to cite the individual for hand-held cell phone use while driving as opposed to texting while driving. Previous traffic safety research concerning Zero Tolerance laws (ie, laws specifying automatic punishments for drinking and driving above a minimum blood alcohol concentration) has also shown that laws with less barriers to enforcement are more likely to be enforced. ${ }^{39}$ Another explanation may have to do with officer behaviour. As hand-held cell phone use bans have generally been in effect longer than texting while driving bans, officers may have formed habits and cite individuals for hand-held cell phone use while driving as opposed to texting while driving. Previous research has shown that officers do form habits in the way in which they cite individuals. ${ }^{18}$
Numerous other factors have been shown to influence citation rates. Research has shown that an officer's personal beliefs can greatly influence their behaviour during police-citizen encounters. ${ }^{13-19}$ Personal or situational characteristics of the driver and/or traffic stop can also influence whether or not a citation is issued including: driver's age, ${ }^{15}$ race, ${ }^{11} 1215$ number of passengers in the stopped vehicle, ${ }^{15}$ the reason for the stop (ie, a roadside check, non-speeding offense, vehicle defect, license/registration check, and driver suspect) ${ }^{15}$ community location (urban vs rural) where the infraction occurred, ${ }^{11} 15$ a driver's criminal record, ${ }^{14}$ presence of bystanders ${ }^{14}$ and condition of the neighbourhood where the stop transpired. ${ }^{16}$ Organisation facets can also influence the number of citations an officer writes, such as management expectations, shift supervisor behaviour, officer capability and opportunity, and perception of rewards. ${ }^{17}$ The size and bureaucratic nature of a 
department can also influence officers' perceived productivity. ${ }^{18}$ Also, whether a law is considered a primary or secondary offense may influence the level of enforcement (eg, primary enforcement allows an officer to apprehend someone for the observed offense alone, whereas with a secondary offense, it must have been committed with a primary offense). ${ }^{40}$

Despite the threat that cell phone use while driving poses to the public, the findings from this analysis show that the number of citations written at the state-level for cell phone use while driving laws, in general, are sparse when compared to other traffic violations. In this study, cell phone use while driving citations comprised $1 \%$ of all written traffic citations, while other studies conducted in single states or jurisdictions found the percentage of cell phone use while driving citations to be $2-8 \%$ of all written citations. ${ }^{21-24}$ Collectively, these findings could indicate that either, (1) drivers are compliant to these laws and that law enforcement does not need to write these citations often, or (2) that enforcement of these laws is low. Given the existing research concerning selfreported cell phone use while driving, road side observed behaviours, and cell phone-related crashes, injuries and deaths, the lack of enforcement may be more suspect. While the citation rates did fluctuate over the years, which was attributed to well-documented bursts of enforcement in certain states, the number of citations written, particularly for texting while driving and young driver all cell phone bans, appeared low. While increasing enforcement may be an obvious method to curb cell phone use while driving, alternate solutions may be needed. Public education or awareness campaigns of state cell phone use while driving laws and the targeting of certain age groups or sexes may be warranted. Possibly changing how these laws are enforced may be another solution. Research conducted by the NHTSA in four states has shown that high visibility enforcement (HVE) may reduce the number of drivers using hand-held cell phones. ${ }^{41}{ }^{42}$ HVE combines strict laws, intense law enforcement, wide-spread media campaigns notifying drivers of impending enforcement, and on-going programme evaluation to deter drivers from using mobile devices while driving. ${ }^{41}{ }^{42}$ While HVE does quickly change driver behaviour, ${ }^{41}$ it is unclear if this type of targeted enforcement changes driver behaviour over a longer period of time, based on what is known about other traffic safety behaviours such as alcohol and seat belt use. ${ }^{43}$ Another potential solution could involve discerning ways to help law enforcement more effectively enforce existing laws. For example, during targeted enforcement campaigns, officers stated that having a higher vantage point (ie, patrolling in taller vehicles) enabled them to better see drivers who were texting and driving. ${ }^{41}$

\section{Strengths and limitations}

The strength of this analysis is that useable citation data was obtained from 14 states and the District of
Columbia. Because of the inclusion of multiple states, a greater wealth of information could be obtained regarding who was cited for cell phone use while driving violations and the number of citations written across multiple states. Despite this strength, this analysis has several distinct limitations. The main limitation was that not all states could provide data and that the types of information in which states collected was highly varied. Hence, only a few variables were homogenous across states and only a few could be analysed. Second, this analysis was based on how the violations were coded. If an officer miscoded the violation (ie, pulled someone over for texting while driving, but wrote it as a hand-held cell phone use violation), the counts could be slightly biased. Third, the rates of enforcement are likely underestimated because this analysis looked at state-level enforcement. Local municipalities may have their own law enforcement and may not contribute their data to a centralised database or they may enforce the laws within their jurisdictions more than state police. Thus, the number of citations written by local police is unknown. Fourth, this study only investigated those who were issued a citation and not necessarily those convicted of the offense, which may differ. Lastly, as mentioned previously, law enforcement is highly discretionary. This analysis sought to describe who was cited for cell phone use while driving violations. Drivers may have engaged in such a behaviour and been pulled over, but simply given a warning by law enforcement.

\section{CONCLUSION}

This analysis sought to determine who was cited for cell phone use while driving and to gauge how many citations were issued among states from 2007 to 2013. The findings suggest that age and sex differences exist among the types of laws violated and that the number of cell phone use while driving citations compared to all other traffic citations written across multiple states was low. Owing to the severity of cell phone use while driving in the USA, more enforcement and targeted public safety campaigns are likely needed.

Contributors TMR and MZ conceived the study. TMR collected the data, analysed the data, and drafted the manuscript. MZ provided technical support and contributed to the intellectual content of the manuscript. TMR and MZ had full access to all the data in the study and take responsibility for the integrity of the data and the accuracy of the data analysis. Both authors contributed to the manuscript preparation and approved the final version.

Funding MZ and TMR received support from grant \#R01HD074594 from the National Institutes of Health, National Institute of Child Health \& Human Development.

\section{Competing interests None declared.}

Ethics approval This study used de-identified citation data collected from states in the United States. IRB approval from West Virginia University was not required because it was waived.

Provenance and peer review Not commissioned; externally peer reviewed.

Data sharing statement No additional data are available. 
Open Access This is an Open Access article distributed in accordance with the Creative Commons Attribution Non Commercial (CC BY-NC 4.0) license, which permits others to distribute, remix, adapt, build upon this work noncommercially, and license their derivative works on different terms, provided the original work is properly cited and the use is non-commercial. See: http:// creativecommons.org/licenses/by-nc/4.0/

\section{REFERENCES}

1. Federal Communications Commission. Local telephone competition reports. https://www.fcc.gov/general/local-telephone-competitionreports (accessed 21 Jan 2016).

2. Sansone RA, Sansone LA. Cell phones: the psychosocial risks. Innov Clin Neurosci 2013;10:33-7.

3. AAA Foundation for Traffic Safety. 2014 traffic safety culture index. Washington DC: AAA Foundation for Traffic Safety, 2015.

4. National Highway Traffic Safety Administration. Driver electronic device use in 2014. Washington DC: Department of Transportation, 2015. HS 812197.

5. Caird JK, Willness CR, Steel P, et al. A meta-analysis of the effects of cell phones on driver performance. Accid Anal Prev 2008;40:1282-93.

6. Simmons SM, Hicks A, Caird JK. Safety-critical event risk associated with cell phone tasks as measured in naturalistic driving studies: a systematic review and meta-analysis. Accid Anal Prev 2016;87:161-9.

7. Collet $\mathrm{C}$, Guillot $\mathrm{A}$, Petit C. Phoning while driving I: a review of epidemiological, psychological, behavioural and physiological studies. Ergonomics 2010;53:589-601.

8. Collet $C$, Guillot $A$, Petit $C$. Phoning while driving II: a review of driving conditions influence. Ergonomics 2010;53:602-16.

9. Horrey WJ, Wickens CD. Examining the impact of cell phone conversations on driving using meta-analytic techniques. Hum Factors 2006;48:196-205.

10. Governors Highway Safety Association. Distracted driving laws. http://www.ghsa.org/html/stateinfo/laws/cellphone_laws.html (accessed 21 Jan 2016).

11. Greenleaf RG, Skogan WG, Lurigio AJ. Traffic stops in the pacific northwest: competing hypotheses about racial disparity. J Ethn Crim Justice 2008;6:3-22.

12. Alpert GP, Macdonald JM, Dunham RG. Police suspicion and discretionary decision making during citizen stops. Criminology 2005;43:407-34.

13. Allen A. Campus officers' explanations of traffic stop sanctions. Police Q 2014;17:276-301

14. Brown RA, Frank J. Police-citizen encounters and field citations. Police: an Int J police strateg Manag 2005;28:435-54.

15. Engel RS, Calnon JM. Examining the influence of drivers' characteristics during traffic stops with police: results from a national survey. Justice Q 2004;21:49-90.

16. Ingram JR. The effect of neighborhood characteristics on traffic citation practices of the police. Police Q 2007:10:371-93.

17. Johnson RR. Management influences on officer traffic enforcement productivity. Int J Police Serv Manag 2006;8:205-17.

18. Mastrofski SD, Ritti RR, Hoffmaster D. Organizational determinants of police discretion: the case of drinking-driving. J Crim Justice 1987; $15: 387-402$

19. Schafer JA, Mastrofski SD. Police leniency in traffic enforcement encounters: exploratory findings from observations and interviews. J Crim Justice 2005;33:225-38.

20. Schafer JA, Carter DL, Katz-Bannister A, et al. Decision making in traffic stop encounters: a multivariate analysis of police behavior Police Q 2006;9:184-209.

21. McCartt AT, Geary LL. Longer term effects of New York State's law on drivers' handheld cell phone use. Inj Prev 2004;10:11-15.
22. McCartt AT, Hellinga LA. Longer-term effects of Washington, DC law on drivers' hand-held cell phone use. Traffic Inj Prev 2007;8:199-204.

23. Maher A, Ott P. Effects of New Jersey's cell phone/text ban. Piscataway, NJ: Rutgers University, 2013:1-37.

24. AAA Foundation for Traffic Safety. Violations and enforcement of graduated driver licensing restrictions in North Carolina and Washington state. Washington DC: AAA Foundation for Traffic Safety, 2014.

25. Federal Highway Administration. Highway statistics series. http:// www.fhwa.dot.gov/policyinformation/statistics.cfm (accessed 15 May 2015).

26. Williams AF, Shabanova VI. Responsibility of drivers, by age and gender, for motor-vehicle crash deaths. J Safety Res 2003;34:527-31.

27. Lonczak HS, Neighbors C, Donovan DM. Predicting risky and angry driving as a function of gender. Accid Anal Prev 2007;39: 536-45.

28. Bachoo S, Bhagwanjee A, Govender K. The influence of anger, impulsivity, sensation seeking and driver attitudes on risky driving behaviour among post-graduate university students in Durban, South Africa. Accid Anal Prev 2013;55:67-76.

29. Rhodes N, Pivik K. Age and gender differences in risky driving: the roles of positive affect and risk perception. Accid Anal Prev 2011;43:923-31.

30. Sivak M. Female drivers in the United States, 1963-2010: from minority to a majority? Traffic Inj Prev 2013;14:259-60.

31. Braitman KA, McCartt AT. National reported patterns of driver cell phone use in the United States. Traffic Inj Prev 2010;11:543-8.

32. Engelberg JK, Hill LL, Rybar J, et al. Distracted driving behaviors related to cell phone use among middle-aged adults. J Transp Health 2015;2:434-40.

33. Tison J, Chaudhary NK, Cosgrove L. National phone survey on distracted driving attitudes and behaviors. Washington DC: Department of Transportation, 2011. DOT HS 811555.

34. Foss RD. Improving graduated driver licensing systems: a conceptual approach and its implications. J Safety Res 2007;38:185-92.

35. Simons-Morton BG, Hartos JL. How well do parents manage young driver crash risks? J Safety Res 2003;34:91-7.

36. Hassan $\mathrm{H}$, King M, Watt $\mathrm{K}$. The perspectives of older drivers on the impact of feedback on their driving behaviours: A qualitative study. Transp Res Part F Traffic Psychol Behav 2015;28:25-39.

37. Foss RD, Goodwin AH, McCartt AT, et al. Short-term effects of a teenage driver cell phone restriction. Accid Anal Prev 2009;41:419-24.

38. Curry AE, Pfeiffer MR, Localio R, et al. Graduated driver licensing decal law: effect on young probationary drivers. Am J Prev Med 2013;44:1-7.

39. Lacey $\mathrm{JH}$, Jones RK, Wiliszowski $\mathrm{CH}$. Zero tolerance laws for youth: four states' experience. Washington DC: Department of Transportation, 2000. DOT HS 809053.

40. Beck LF, Shults RA, Mack KA, et al. Associations between sociodemographics and safety belt use in states with and without primary enforcement laws. Am J Public Health 2007;97:1619-24

41. Chaudhary NK, Casanova-Powell TD, Cosgrove L, et al. Evaluation of NHTSA distracted driving demonstration projects in connecticut and New York. Washington DC: Department of Transportation, 2014 DOT HS 811635

42. National Highway Traffic Safety Administration. Distracted driving high-visibility enforcment demonstrations in California and Delaware. Washington DC: Department of Transportation, 2014. DOT HS 811 993.

43. Solomon MG, Nissen WJ, Preusser DF. Occupant protection special traffic enforcement program evaluation. Washington DC: Department of Transportation, 1999. DOT HS 808884. 